\title{
KEDUDUKAN HUKUM HAK ULAYAT MASYARAKAT HUKUM ADAT DIHUBUNGKAN DENGAN OTONOMI DAERAH (STUDI DI KECAMATAN HARIAN KABUPATEN SAMOSIR)
}

\author{
Oleh: \\ Mangapul Marbun. \\ Universitas Darma Agung, Medan \\ E-mail: \\ Mangapul13@yahoo.com
}

\begin{abstract}
The position of the customary rights of the customary law community in the Toba Batak community, namely the rights owned by a clan (State land), controlled, managed, utilized, the land and its contents for the needs of the citizens / descendants of the partnership as collective property that can be passed down from generation to generation (geneological) based on customary law. The UUPA recognizes the position of the ulayat rights of the customary law community in a formal juridical manner with discussion if in reality it still exists and does not conflict with the interests of the national, nation and state. The 1945 Constitution of the Republic of Indonesia Article 18-B paragraph (2), Article 28-I paragraph (3) The State recognizes and respects the customary public and their traditional rights as long as they are still alive. The cultural identity of traditional community rights is respected in accordance with the times and civilizations. The position of the customary rights of the Batak Toba community (land marga) in this study is still not as expected, in regulating and protecting laws from the past to the present, regulation and protection are still based on local customary laws. In Law No. 23/2014/9/2015 concerning Regional Government grants the authority of rights and responsibilities to provincial, regency / city governments to regulate and manage their own regions, one of the areas of defense based on the widest possible regional autonomy. The authority, rights and responsibilities of regional governments in regulating and protecting, managing their own ulayat rights (clan land) in certain areas are also in line with Presidential Decree No. 34 regarding policies in the defense sector, one of which is stipulation and is also in line with the government regulation of the Republic of Indonesia No. 38 Year 20007 concerning the Division of Government Affairs between the government and the Provincial Government of the Regency / City Government as a government affair which becomes the authority of the regional government towards the position of the ulayat rights of the customary law community in certain areas. In this study, in the Daily District of Samosir Regency. The authority, rights and obligations of Regional Government through stipulation in the form of Regional regulations have not been implemented, especially regarding local clan lands (ulayat rights of indigenous peoples). Therefore, this problem needs to be researched to get a true picture of the status of customary community rights in relation to regional autonomy in the Daily District of Samosir Regency. The results of this study, in the Samosir Kewenagan Regency Daily sub-district, the rights and obligations of regional government, it turns out that Tanah Marga (Hak Ulayat) is still regulated by local customary law, in fact the
\end{abstract}


local government has the authority, rights and obligations to regulate and protect Ulayat Rights (Tanah Marga). certain by stipulation in the form of regional regulations, with the aim of providing legal certainty and benefits for the customary law community. Based on the research, it shows that the Land of Marga / Ulayat Rights of Indigenous Peoples in Harian District, generally in Samosir Regency, both horizontally and vertically until this research was conducted, there has been no settlement of certain customary rights of customary communities, in other words conflict resolution is still stagnant. The government needs to immediately establish the customary rights of customary communities in the form of a law. To ensure legal certainty / benefit and justice for all certain Customary law communities. Because ulayat rights are basically still found and still live according to the civilization of the Batak Toba people in the Daily District of Samosir Regency, which does not conflict with the development and interests of the Nation and the State.

Keywords: Customary Law, Customary Rights, Regional Autonomy

\begin{abstract}
ABSTRAK
Kedudukan Hak Ulayat Masyarakat Hukum Adat pada masyarakat Batak Toba yaitu hak yang dimiliki oleh suatu marga (tanah Negara),dikuasai, dikelola, dimanfaatkan tanah dan seisinya untuk keperluan warga/keturunan dari persekutuan sebagai milik bersama yang dapat diwariskan secara turun-temurun (geneologis) berdasarkan hokum adat. UUPA mengakui kedudukan hak ulayat masyarakat hokum adat secara yuridis formal dengan pembahasan jika dalam kenyataannya masih ada dan tidak bertentangan dengan kepentingan nasional, bangsa dan Negara. UUD RI 1945 pasal 18-B ayat (2), pasal 28-I ayat (3) Negara mengakui dan menghormati masyarakat umum adat serta hak tradisionalnya sepanjang masih hidup. Identitas budaya hak masyrakat tradisional dihormati selaras dengan perkembangan zaman dan peradaban. Kedudukan hak ulayat masyarakat (tanah marga) Batak Toba dalam penelitian ini masih belum sesuai dengan yang diharapkan, dalam pengaturan dan perlindungan hokum dari masa silam sampai sekarang, pengaturan dan perlindungan masih berdasarkan hokum adat setempat. Dalam Undang-Undang No. 23 Tahun 2014/No.9 Tahun 2015 tentang pemerintahan Daerah memberikan kewenangan hak dan kewajiaban kepada pemerintah daerah provinsi, kabupaten/kota untuk mengatur dan mengurus sendiri daerahnya salah satu bidang pertahanan berdasarkan otonomi daerah yang seluas-luasnya. Kewenangan, hak dan kewajiaban pemerintahan daerah dalam mengatur dan melindungi, mengurus sendiri hak ulayat (tanah marga) di daerah tertentu sejalan juga dengan keputusan Presiden Nomor 34 tentang kebijakan di di bidang pertahanan, salah satunya penetapan dan sejalan juga dengan peraturan pemerintahan Republik Indonesia Nomor 38 Tahun 20007 Tentang Pembagian Urusan Pemerintahan antara pemerintahan dengan pemerintahan Daerah Provinsi Pemerintahan Kabupaten/Kota sebagai urusan pemerintahan yang menjadi kewenangan pemerintahan daerah terhadap kedudukan hak ulayat masyarakat hokum adat di daerah tertentu. Pada penelitian ini, di Kecamatan Harian Kabupaten Samosir Kewenangan, hak dan kewajibanPemerintahan Daerah melalui penetapan dalam bentuk peraturan Daerah belum dilaksanakan khususnya mengenai tanah marga ( hak ulayat masyarakat hokum adat) setempat. Oleh karenanya permasalahan ini perlu diteliti untuk mendapatkan gambaran yang
\end{abstract}


sebenarnya mengenai Kedudukan Hak Ulayat Masyarakat Hukum Adat berhubungan Dengan Otonomi Daerah di Kecamatan Harian Kabupaten Samosir. Hasil penelitian ini, di kecamatan Harian Kabupaten Samosir Kewenagan, hak dan kewajiban pemerintahan Daerah, ternyata Tanah Marga (Hak Ulayat) masih diatur oleh hokum adat setempat, sebenarnya pemerintah daerah mempunyai kewenangan, hak dan kewajiban untuk mengatur dan melindungi Hak Ulayat (Tanah Marga) tertentu dengan penetapan dalam bentuk peraturan daerah, dengan maksud untuk memberikan kepastian hokum dan kemanfaatan bagi masyarakat hokum adat. Berdasarkan penelitian menunjukan masih rentan Tanah Marga/Hak Ulayat Masyarakat Adat di Kecamatan Harian, umumnya Kabupaten Samosir, baik secara horizontal dan vertical sampai penelitian ini dilakukan, belum ada penyelesaian Hak Ulayat Masyarakat Hukum Adat tertentu, dengan kata lain penyelesaian konflik masih stagnan. Pemrintah perlu, segera melakukan penetapan Hak Ulayat Masyarakat Hukum Adat dalam bentuk undang-undang. Untuk menjamin kepastian hukum/kemanfaatan dan keadailan bagi seluruh masyarakat hokum Adat tertentu. Karena hak ulayat pada dasarnya masih banyak dijumpai dan masih hidup sesuai peradaban masyarakat Batak Toba di Kecamatan Harian Kabupaten Samosir, yang tidak bertentangan dengan pembangunan serta kepentingan Bangsa dan Negara.

\section{Kata kunci : Hukum Adat, Hak Ulayat, Otonomi Daerah}

\section{PENDAHULUAN}

Di dalam Negara Republik Indonesia yang susunan kehidupan rakyatnya, termasuk perekonomiannya, terutama masih bercorak agraris, bumi, air dan ruang angkasa sebagai Karunia Tuhan Yang Maha Esa mempunyai fungsi yang adil dan makmur, sebagaimana tercantum dalam bagian menimbang tentang peraturan pokok undang-undang pokok agraria. bahwa hukum agraria nasional pula, perikemanusian, seperti yang tercantum dalam pembukaan UndangUndang Dasar Negara Republik Indonesia 1945

Sejak kemerdekaan Undang-undang Pokok Agraria No. 5 Tahun 1960 telah mengakhiri kebhinekaan (keberagaman) perangkat hukum yang mengatur bidang pertanahan, yang didasarkan pada hukum adat dan mengadakan unifikasi hak-hak penguasaan atas tanah, baik hak-hak tanah maupun hak-hak jaminan atas tanah, Pembentukan Undang-undang Pokok
Agraria dengan berdasarkan hukum adat, memberikan arti sebagai pengakuan terhadap masyarakat hukum adat dan Hak Ulayat Yang pada masa Klonialisme pengaturan hak-hak atas tanah telah terjadi dualisme, satu sisi dengan pengaturan hukum Barat dengan Agrarische Wet, dan bagi kaum pribumi berlaku hukum adatnya masing-masing.

Pengakuan kedudukan hukum secara yuridis formal ditentukan didalam pasal 3 dan pasal 5 Undang-undang Pokok Agraria No. 5 Tahun 1960. Pasal 3 menyatakan : dengan mengingat ketentuan pasal 1 dan 2 pelaksanaan hak ulayat dan hak yang serupa itu dari masyarakat hukum adat, sepanjang kenyataannya dan peraturan lain yang lebih tinggi, Pasal 2 ayat (4) yang berbunyi : Hak menguasai dari negara tersebut diatas pelaksanaannya dapat dikuasakan kepada daerah-daerah swatantra dan masyarakat-masyarakat hukum adat setempat, menurut ketentuan-ketentuan pemerintah, undang- 
undang ini dan peraturan perundangan lainnya, segala sesuatu dengan mengindahkan unsur-unsaur yang bersandar pada hukum agama". Atas ketentuan pasal 3 dan pasal 5 UUPA diatas telah mengakui pelaksanaan hak ulayat dari masyarakat hukum adat sepanjang kenyataannya masih ada dan hukum agraria didasarkan pada hukum adat sebagai hukum pertanahan Nasional. Dalam hal ini sejalan dengan landasan konstitusional UUD 1945 sebagai norma tertinggi dalam sistem hukum (staatfundamentalnorm) setelah Amademen ke IV yang ditegaskan berikut. Dalam Pasal 18B ayat (2) menyatakan Negara mengakui dan menghormati kesatuan-kesatuan masyarakat hukum adat serta hak-hak tradisionalnya sepanjang masih hidup. Pasal 28I ayat (3) menyatakan : Identitas budaya dan hak masyarakat tradisional dihormati selaras dengan perkembangan zaman dan peradaban. Pasal 33 ayat (3) di dalam pengakuan kedudukan hukum sangat penting menyangkut persoalan sosial dan hukum yaitu tentang sistem penguasaan agraria masyarakat tradisional Indonesia khususnya dalam hukum formal di dalam Undang-undang Pokok Agraria tentang pengaturan hukum pertanahan nasional.

\section{TINJAUAN PUSTAKA}

Berdasarkan UU No. 22 Tahun 1999 Tentang Pemerintahan Daerah dalam Bab III telah ditentukan Pembentukan Dan Susunan Daerah, selanjutnya dipertegas dalam Pasal 4 ayat (1), dan dalam Bab IV telah mengatur Kewenangan Daerah yang disebutkan dalam Pasal 7 ayat (1) yang menyatakan : Kewenangan Daerah mencakup kewenangan dalam seluruh bidang pemerintahan, kecuali kewenangan dalam bidang politik luar negeri, pertahanan keamanan, moneter dan fiskal, agama serta kewenangan bidang lain.

Selanjutnya dalam pasal 11 ayat (1) dan asyat (2) UU No. 22 Tahun 1999. Pasal 11 ayat (1) diatur dalam pasal 9. Pasal 11 ayat (2) menyatakan : bidang pemerintahan yang wajib dilaksanakan oleh daerah Kabupaten / Kota, meliputi pekerjaan umum, kesehatan , pendidikan dan kebudayaan, pertanian , perhubungan, dan salah satunya pertanahan, dan dengan demikian daerah Kabupaten / Kota mempunyai kesempatan dan peluang untuk mengatur dan mengurus rumah tangga daerahnya salah satunya bidang pertanahan, yang maksud dan tujuannya memberikan pengakuan dan perlindungan hukum atas kedudukan hukum hak ulayat masyarakat adat, hal mana berdasarkan otoritas Otonomi Daerah. Maka Pemerintah Daerah berhak membuat penetapan hak ulayat Kabupaten / Kota untuk kepentingan tersebut.

\section{METODE PENELITIAN}

Ilmu pengetahuan pada hakekatnya timbul oleh karena ada hasrat ingin tahu dalam diri manasia . keigintahuan manuasia tentang seseuatu adalah untuk mencari kebenaran. Dalam mencari kebenaran tersebut manusia menempuh berbagai macam cara ; baik melalui kegiatan ilmiah maupun non ilmiah. Pekerja penelitian adalah sebuah pekerjaan dengan mengumpulkan berbagai macam bahan yang berrhubungan dengan penelitian yang tengah dilakukan.hal ini timbul karena adanya masalah,tanpa adanya masalah tidak ada penelitian. Dalam penelitian 
dipergunakan jenis penelitian yaitu penelitian hukum yurudis sosiologis.

Penelitian yuridis sosiologis adalah jenis penelitian yang fokus pada gejala hukum yang timbul ditengah-tengah masyarakat. Spesifikasi yang digunakan dalam penelitian ini bersifat penelitian dan bersifat penelitian deskriptif analisi yaitu dimaksud untuk mencari data yang seteliti mungkin tentang suatu keadaan atau gejala lainnya. Sifat penelitian ini adalah penelitian hukum analitik. Deskriptif artinya menggambarkan apa adanya. Jadi didalam penelitian ini, penulis akan menggambarkan atau menelaah permasalahan hukum pertahanan (agraria) secara tradisional yang sedang terjadi dikecematan Harian kabupaten samosir kususnya mengenai " Kedudukan hak ulayat msyarakat hukum adat di hubungkan dengan otonomi daerah studi di kecamatan Harian kabupaten samosir, pran pemerintah daerah dalam mengatur dan melindungi hak ulayat masyarakat Hukum Adat, serta peran pemerintahan Daerah dan tokoh masyarakat Hukum adat dalam penyelesian konflik terkait dengan hak ulayat masyarakat Hukum Adat.

Analisis artinya data-data dari terkait hasil penelitian ini akan diolah terlebih dahuku,dianalisis serta diuraikan secara cermat berdasarkan perundang-undangan terutama yang berhubungan dengan pertahanan dan hukum adat yang msih hidup dan berkembang tentang “ Kedudukan Hak Ulayat Masyarakat Hukum Adat hubungan dengan Otonomi Daerah di tempat studi kecematan Harian Kabupaten Samosir.

\section{HASIL DAN PEMBAHASAN}

Peraturan perundang-undangan diatas dipertegas lagi dengan keluarnya UU No. 32 Tahun 2004 tentang pemerintahan daerah, dalam Pasal 2 ayat (1) yang menyatakan : Indonesia dibagi atas Daerah Provinsi dan Daerah Provinsi dibagi atas Daerah Kabupaten Kota yang masingmasing mempunyai pemerintahan Daerah. Selanjutnya pasal 2 ayat (2) menyatakan : Pemerintah Daerah sebagaimana dimaksud pada ayat (1) mengatur dan mengurus sendiri urusan pemerintahan menurut asas otonami dan tugas pembantuan. Pada pasal 2 ayat (3) menyatakan : Pemerintah Daerah sebagaimana dimaksud pada ayat (2) menjalankan otonomi seluas-luasnya, kecuali urusan pemerintah yang menjadi urusan pemerintah, dengan tujuan meningkatkan kesejahteraan masyarakat, pelayanan umum dan meningkatkan daya saing daerah.

Selanjutnya dalam UU No. 23 Tahun 2014 tentang Pemerintahan Daerah pada Bab II telah menegaskan tentang Pembagian Wilayah Negara yaitu dalam Pasal 2 ayat (1) yang menyatakan : Negara Kesatuan Republik Indonesia dibagi atas Daerah Provinsi dan Daerah Provinsi dibagi atas Daerah Kabupaten dan Kota. Dalam ayat (2) menyatakan : Daerah Kabupaten/Kota, dan Kabupaten/Kota dibagi atas Kecamatan, dan Kecamatan dibagi atas Kelurahan/Desa. Maka atas peraturan perundang-undangan tersebut, secara jelas otoritas Pemerintah Daerah mempunyai kewenangan melakukan Peraturan Daerah Kabupaten/Kota, dalam hal mengatur, melindungi kedudukan hak.

Terkait dengan kewenangan Pemerintah Daerah tersebut yang berdasarkan otonomi, Kabupaten Samosir 
adalah salah satu Daerah Otonom dari 25 Kabupaten dan 8 Kota di Provinsi Sumatera Utara, dengan titik kordinat 20 $24^{0}-2055^{0} \mathrm{LU}$, dan $98021^{0}-99055^{0}$ BT, dengan luas wilayah $2.021,80 / \mathrm{Km}^{2}$. dengan ketinggian permukaan bumi 9042.157M diatas permukaan laut, jumlah penduduk 150.187 jiwa, daerah pertanian (agraris), dengan batas-batas wilayah : Sebelah Utara berbatas dengan Kabupaten Karo, dan Kabupaten Simalungun, Sebelah Selatan berbatas dengan Kabupaten Tapanuli Utara dan Kabupaten Humbang Hasundutan, Sebelah Timur berbatas dengan Kabupaten Toba Samosir, dan Sebelah Barat berbatas dengan Kabupaten Dairi dan Pakpak Barat.

Kabupaten Samosir 128 Desa/Kelurahan dan terdiri dari 9 (Sembilan) Kecamatan, dan dari 128 Desa/Kelurahan tersebut diantaranya sebagai tempat (Studi di Desa Hutagalung, Partungko Naginjang dan Desa Hariarapintu Kecamatan Harian), yang terletak sebelah selatan Kabupaten Samosir. Dengan batas-batas Sebelah Utara berbatas dengan Kecamatan Sianjur Mula-mula dan Pantai Danau Toba, Sebelah Selatan berbatas dengan Kabupaten Humbang Hasundutan, Sebelah Timur berbatas dengan Kecamatan SitioTio, Sebelah Barat berbatas dengan Kabupaten Dairi dan Kabupaten Pak-Pak Barat. Penduduknya Suku Batak Toba $100 \%$ (homogen) dan bermarga, yang mempunyai adat istiadat (tradisi) dan kebiasaan, secara turun-temurun dan hidup sampai sekarang. Adat istiadat tersebut berlaku secara terus menerus yang menjadi norma yang tidak tertulis baik secara perdata maupun publik. Hal ini berlaku juga dalam pengaturan, penggunaan dan pemanfaatan hak-hak atas tanah marga " golat " masyarakat hukum adat dalam bidang agraria yang masih tradisional. Dalam masyarakat Batak Toba hak-hak atas tanah dikenal dengan Tanah Marga (golat, talian) yang artinya tanah adalah milik/dikuasai secara bersama-bersama para anggotaanggotanya dan untuk mengambil hasil dari tanah tersebut demi kehidupan dan kesejahteraan anggotanya yang berlaku kedalam dan keluar, yang berdasarkan hukum adatnya secara turun temurun dan dengan istilah (marga do nampuna tano), bagi Orang Batak “ arga do bonani pinasa “ dan suatu prinsip yang diterimanya sebagai prinsip dasar hukum adat tanah.

Pemilikan atas tanah marga (golat, talian) didasarkan pada penguasaan/menduduki tanah pertama sekali dan telah mendirikan kampung (mamukka huta) oleh marga tersebut terlebih dahulu. Khususnya ditempat (studi) pada Desa Partungko Nagijang, Hariara Pintu dan Desa Hutagalung Kecamatan Harian Kabupaten Samosir masih terdapat tanah-tanah Adat (marga) " golat ", dan dalam kepustakaan hukum Adat yang oleh Cornelius van Vallenhoven disebut " besihikkingrecht ", dan dalam hukum agraria secara umum disebut “ hak ulayat " masyarakat hukum adat.

Dalam ketentuan UUPA Pasal 3 dan Pasal 5, serta dalam ketentuan UUD 1945 Pasal 18B ayat (2), Pasal 28I ayat (3) dan Pasal 33 ayat (3) setelah Amandemen IV Tahun 2002, tidak di implementasikan Pemerintah Daerah Kabuapten Samosir untuk membuat Penetapan Hak Ulayat dalam bentuk Peraturan Daerah (PERDA) atas tanah Hak Ulayat masyarakat hukum adat sesuai UU No. 22 Tahun 1999, UU 
No, 32 Tahun 2004, UU No. 23 Tahun 2014, dan sekarang UU No. 9 Tahun 2015. Yang ditegaskan dalam Pasal 11 ayat (2) menyatakan : bidang pemerintahan yang wajib dilaksanakan oleh Daerah Kabupaten/Kota meliputi pekerjaan umum, kesehatan, pendidikan dan kebudayaan, pertanian, perhubungan dan salah satunya pertanahan, dan dengan demikian Daerah Kabupaten/Kota mempunyai kesempatan dan peluang untuk mengatur dan mengurus rumah tangga daerahnya salah satunya dibidang pertanahan, yang maksud dan tujuannya memberikan pengakuan dan perlidungan hukum atas kedudukan hak ulayat masyarakat adat.

Dengan demikian ketentuan tersebut memerintahkan, Pemerintah Daerah untuk mengatur perlindungan hukum, penggunaan dan pemanfaatan hak ulayat masyarakat hukum adat, termasuk kesatuan-kesatuan masyarakat hukum adat dan hak-hak tradisionalnya dalam bidang agraria. Hal tersebut belum dilaksanakan oleh Pemerintah Kabupaten Samosir, sehingga menyebabkan pengaturan Tanah Marga (golat, turpuk, talian) menjadi tidak jelas dalam hukum positif Indonesia (tidak ada kepastian hukum) dalam hukum positip. Khususnya menyangkut "Kedudukan Hukum Hak Ulayat Masyarakat Hukum Adat Di Hubungkan Dengan Otonomi Daerah Tempat (Studi) Desa Hutagalung, Desa Partungko Nagijang dan Desa Hariara Pintu Kecamatan Harian Kabupaten Samosir. Dimana pengaturan yang dimaksudkan sebagai komitmen dan upaya dari Negara melalui kewenangan Pemerintah Daerah (PEMDA) sebagai Otoritas atas Otonomi Daerah untuk mengatur, penggunaan, pemanfaatan, serta mengembalikan hak-hak masyarakat hukum adat yang selama ini terabaikan, yaitu dengan membuat Penetapan Hak Ualyat (PERDA) demi keadilan, perlindungan, kemanfaatan dan kepastian hukum atas penguasaan tanah hak ulayat masyarakat hukum adat tertentu.

Terkait ketentuan-ketentuan dari Peraturan perundang-undang tentang pengaturan, dan perlindungan dengan Penetapan sebagai kewenangan Kepala Daerah Provinsi dan Kabupaten/Kota berdasarkan Otonomi Daerah, yang dijelaskan diatas secara nyata, Pemerintah Kabupaten Samosir belum melaksanakannya, oleh karenanya antara harapan dengan kenyataan telah terjadi kesenjangan, bahwa peraturan perundangundangan dengan kenyataan ditengah masyarakat telah berbeda. Maka atas permaslahan ini penulis tertarik untuk melakukan (studi) secara khusus di Desa Hutagalung, Desa Partungko Nagijang , dan Desa Hariara Pintu Kecamatan Harian Kabupaten Samosir.

\section{SIMPULAN}

Simpulan:

1. Kedudukan Hak Ulayat Masyarakat Hukum Adat Batak Toba di Kecamatan Harian Kabupaten Samosir adalah "Tanah Marga", dan sampai saat ini masih eksis. Hak tersebut dimiliki oleh suatu marga, dikuasai, dikelola, dimanfaatkan tanah dan seisinya untuk keperluan warga/keturunannya dari persekutuan sebagai milik bersama dapat diwariskan secara turun-temurun (geneologis, teritorial) berdasarkan hukum 
adat. Tanah marga meliputi perkampungan (Huta), tanah ladang, pemakaman (kuburan), Hutan, sungai, pohon-pohonan (tempat pemujaan roh). Kewenangan Subjek marga tanah didasarkan atas hak menguasai pertama sekali/mamukka huta (mendirikan perkampungan paling pertama sekali), dan marga mempunyai wewenang mengatur secara intern dan ekstern berdasarkan hukum adat. Kewenangan untuk mengatur ditangan Raja Doli keturunan yang tertua (anak sulung). Tanah marga-marga yang bersifat kewilayahan (Bius) adalah tanah yang dikuasai, dan dipergunakan kepentingan bersama, secara wilayah yang sejak semula marga-marga mengadakan kesepakatan kewilayahan atas tanah tertentu, dan tanah seperti ini pada tempat penelitian tidak begitu kuat lagi subjeknya, dan objeknya semakin tidak jelas pada masa sekarang.

Kedudukan (tanah marga) kenyataannya masih relatif kuat karena tetap dipertahankan (pemilikan, pewarisan, dan pengalihan) sesuai dengan hukum adat masyarakat Batak Toba dari masa silam sampai sekarang diatur yang tidak tertulis.

2. Peraranan Pemerintah daerah dalam mengatur dan melindungi hak ulayat masyarakat hukum adat di Kecamatan Harian
Kabupaten Samosir, dalam penelitian menunjukkan belum dilaksanakan sebagaimana yang diatur dalam berbagai peraturan perundang-undangan karena :

a. Masih ada permasalahan baik secara horizontal antara sesama kelompok pemilik hak ulayat, dan Badan usaha, maupun secara vertikal terhadap Pemerintah yang saling mengklaim tentang subjek, batas-batas, dan ukuran tidak jelas

b. Belum ada kelembagaan yang bersifat formal yang dibentuk oleh Pemeritah Daerah atas masyarakat hukum adat, sebagai salah satu syarat Penetapan Hak Ulayat

a. Belum dilakukan verifikasi tertentu secara jelas oleh Pemerintah Daerah.

b. Masyarakat hukum adat kurang aktif melibatkan diri dalam partisipasi verifikasi kelembagaan hukum adat, dan verifikasi hak ulayat tertentu.

3. Dalam Penyelesaian Konflik terkait dengan Hak Ulayat Masyarakat Hukum Adat (tanah marga), peranan yang dilakukan oleh Pemerintah daerah dan Tokoh Masyarakat Hukum Adat di tempat studi di Kecamatan Harian Kabupaten Samosir adalah :

a. Sebagai mediator bagi pihakpihak yang sedang berkonflik secara horizontal antara sesama kelompok pemegang 
( tanah marga), Badan

Hukum, untuk melakukan musyawarah mufakat

bersama dengan unsur

Pimpinan Hukum Adat, sekaligus sebagai notulen atas berhasil tidaknya musyawarah mufakat pihakpihak.

b. Sebagai internal Unsur Pimpinan Dearah, dan Tokoh Masyarakat Hukum Adat dengan bersama-sama memberikan fasilitator dan motivator bagi masyarakat hukum adat untuk memperjuangkan hak ulayat (tanah marga) atas konflik secara vertikal terhadap Pemerintah

c. Sebagai Internal Unsur Pimpinan daerah dan masyarakat Hukum Adat secara bersama-sama melakukan keamanan dan stabilisator bagi pihak-pihak kelompok masyarakat hukum adat pemilik hak ulayat, dan badan hukum, yang sedang berkonflik atas tindakan yang bertentangan dengan hukum.

\section{Saran:}

1. Diharapkan Pemerintah tidak sekedar melakukan Pengakuan atas Kedudukan Hukum UUPA, tetapi harus ada Prolegnas sebagai instrument perencanaan pembentukan peraturan perundang-undangan tingkat pusat yang memuat skala prioritas legislasi, terpadu, sistematis. Dengan Prolegnas peraturan perundang-undangan menjadi harmonis lebih tinggi dengan lebih rendah selaras sebagai payung hukum hak ulayat secara yuridis formal.

2. Diharapkan permasalahan tanah marga pada tempat penelitian, segera dapat diatasi dengan melaksanakan Penetapan hak ulayat masyarakat hukum adat tertentu dalam bentuk Peraturan Daerah oleh Pemerintah Daerah, sebagai konsistensi dari Peraturan perundang-undangan yaitu dengan hukum tertulis bagi pemegang tertentu secara yuridis formal.

3. Supaya penyelesaian konflik baik secara horizontal maupun vertikal, Pemerintah Daerah dan Tokoh Masyarakat Hukum Adat tidak hanya sebagai fasilitator dan mediator saja, dan tidak melakukan pembiaran hanya untuk kepentingan politik penguasa saja, tetapi harus sungguh-sungguh mengambil kebijakan yang pro kepentingan masyarakat hukum adat untuk memperjuangkan hak ulayat (tanah marga) yang sedang menghadapi konflik secara vertikal terhadap Pemerintah, masyarakat hukum adat merupakan bagian internal Pemerintahan Daerah dengan Otonomi Daerah dalam bingkai Negara Kesatuan Republik Indonesia sesuai dengan UUD NKRI 1945. 


\section{DAFTAR PUSTAKA}

UUPA No. 5 Tahun 1960, Tentang

Peraturan Dasar Pokok-Pokok Agraria

Republik Indonesia

Rosnidar Sembiring, Hukum Pertanahan

Adat, Penerbit PT Grafindo Persada,

Depok,2017

UUD, setelah Amandemen I, II, III, IV.

Permata Press.2011, hlm. 219, 230.

UU Tentang Pemerintahan Daerah, No. 22

Tahun 1999.

UU Tentang Pemerintahan Daerah, No. 32

Tahun 2004

UU, Tentang Pemerintahan Daerah, No, 32

Tahun 2004
Data Geografis Kabupaten Samosir, Dinas Komunikasi Dan Informatika Kabupaten Samosir,2020, http://samosirkab.go.id geografis.

Data Analisais Penetapan Wilayah Pembangunan kabupaten Samosir, 2020 htttps://core.ac.uk.pdf

J.C. VERGOUWEN, T. O. IHROMI, Masyarakat Dan Hukum Adat Batak Toba, Penerbit Pustaka Azet, Jakarta, 2019 ,

UU Tentang Pemerintahann Daerah,No. 22 Tahun 1999, UU Tentang Pemerintahan Daerah, yang diperbaharui No. 32 Tahun 2004, UU Pemerintahan Daerah, Yang diperbaharui, No. 23 Tahun 2014, UU Tentang Pemerintahan Daerah, yang diperbaharui, No. 9 Tahun 2015. 